\title{
Portugal - Political Repercussions of the Financial Rescue Plan
}

\begin{abstract}
When in early 2011 Portugal's socialist Prime Minister José Sócrates had to submit to a $€ 78 \mathrm{bn}$ bailout from the troika of the European Union, the European Central Bank and the International Monetary Fund, 40 years of democratic, social and economic development came to a close. In April 1974 a long-running dictatorship was overthrown and the process of creating a democratic state began. With Portugal's 1986 accession to the (then) European Communities, development funds were made available and hopes were high for a successful convergence to the coveted living standards of Northern Europe. What followed only partially lived up to expectations. Portugal had some success in attracting low-wage industries and built up a viable tourism industry. Most importantly, though, the state expanded and grew intertwined with many sectors of the economy, while large amounts of money were spent on infrastructure such as basic sanitation and highways. Electoral politics, dominated by the ambition to turn Portugal into a modern European country, demanded ever greater promises of higher public employment, salaries, pensions, tax deductions and health care spending. The 1990s were good years, with palpable economic growth, a transformation of citizens into consumers and a general feeling that the state had plenty of money to spend to make life better. At the end of the century, Portugal was a radically different place from what it had been only a few decades before.
\end{abstract}

Then came a full decade of stagnation. Increasing globalisation led to a breakdown of the export-based part of Portugal's economy, as jobs were relocated eastwards. The legal system had become so complicated that private individuals and business were becoming strangled by millions of legal proceedings gathering dust in overloaded courts. Much of the adult population had received only the most basic education, leading to low productivity at work and diminished chances at school for their own children. Portugal's most successful companies were primarily dependent on rents in the domestic market. The overhang of acquired rights and benefits in public spending could no longer be financed by the small income and corporate tax bases. When the US subprime crisis transmogrified into a European sovereign debt crisis, Portugal stood no chance. The interest rates on public debt quickly rose above $7 \%$, and taking on more public debt became impossible.

This short sketch helps to explain what happened next. Elections in April 2011 brought Pedro Passos Coelho to power. The new government, with technocratic Finance Minister Vítor Gaspar and a junior coalition party led by Paulo Portas, determinedly set out to make Portugal a viable country by reducing public spending and reforming the state in line with the memorandum agreed to by the previous government. The yearly budget deficit was to be reduced from about $10 \%$ in 2010 to $5.9 \%, 4.5 \%$ and $3 \%$ in the following three years. Labour market rules which dated back to the 1974 revolution and made firing workers almost impossible were to be reformed to make hiring attractive again. Most importantly, following the credo that high public debt was the principal cause of low growth (rather than being the result of low growth), the government embarked on a path of strict austerity.

The two most critical items in the budget were the salaries and pensions of public employees. Thus "cutting the fat" first meant reducing these salaries and pensions by up to $10 \%$. Additionally, the VAT was increased to $23 \%$ on a range of goods (including electricity and restaurants). Then the government decided to cut one of the 14 instalments (12 months plus holiday and Christmas "subsidies") of public employees' salaries and pensions while raising their social security contributions. The communist CGTP trade union rejected all these measures, but the centre-right UGT trade union and employers' representatives gave 
their support. The trade deficit closed through an uptick in exports and a strong reduction in imports. Things seemed to look up, or at least to stop getting worse.

Still the government pressed on. It cut the second annual subsidy, bringing the total income reduction to $30 \%$ for some public employees. It also tried to reduce firms' labour costs by lowering their social security contributions and financing this by increasing those of the workers. This latter measure was a seemingly clever variant of what was agreed to with the Troika, to be financed by a VAT increase. But not only was the government's proposal economic nonsense (total wage costs would increase, not decrease), it was so unpopular that the government lost much of its credibility. Huge demonstrations ensued, and the government backed down.

Then the Constitutional Court entered the fray, declaring the subsidy cuts unconstitutional because they treated public and private sector employees differently. In response, the government reversed one subsidy cut but instead increased the income tax for all workers, such that one subsidy would be taxed away. The Constitutional Court was not satisfied, and in April 2013 it struck down cuts in unemployment and illness benefits and, most importantly, the first subsidy cut for public employees, again on equity grounds. This left the government even more hard-pressed to balance its finances. Some proposed measures, such as further pension cuts combined with a solidarity tax on the largest pensions, led to strong frictions between the coalition partners, giving rise to contradicting public declarations about "red lines" by the leaders of the two ruling parties.

After two years of following the bailout conditions line by line, Portugal now finds itself mired in a steep recession. It has suffered a rise in unemployment from below $10 \%$ to $18 \%$ and a public debt that has increased from about $80 \%$ of GDP to $120 \%$ (and that will top out beyond $130 \%$ ). The country also has a generation of young people who either have received insufficient education or who will follow Angela Merkel's calls to emigrate and work in healthier countries such as Germany - but also Angola, Brazil and Mozambique. Needless to say, none of the predictions about reaching deficit limits or getting back to economic growth have come true. The IMF was forced to admit that the fiscal multiplier, i.e. the reduction in GDP for each euro less in government spending, was not smaller than 1 (as the IMF had predicted) but in fact larger - each additional cut to the budget reduced GDP by more than the savings from the cut. A generalised economic slowdown in the rest of Europe closed the only remaining escape valve.

In July 2013, Finance Minister Gaspar finally stepped down, arguing that the consistent failure of all economic predictions and divisions within the government made it impossible for him to continue. Soon thereafter, Mr Portas, the junior coalition party leader, also stepped down. In the ensuing crisis, interest rates on the secondary debt market spiked, as significant doubts were raised about Portugal's ability to continue its path of consolidation. After a few days of negotiation, both coalition partners hammered out a new agreement, with Mr Portas becoming Deputy Prime Minister directly in charge of the relationship with the troika. In a surprising step, Portugal's President Haníbal Cavaco Silva brushed this agreement aside and appealed to the three main political parties to form a government of "national salvation". During a week of repeated negotiations, an agreement proved elusive, in part because the opposition party was fully aware that entering an agreement would only spoil its chances of winning the next parliamentary elections hands down.

Steffen Hoernig, Universidade Nova de Lisboa, Lisbon, Portugal.
At the time of writing it is still unclear whether the existing government will continue or whether a new technocratic government will be formed by presidential initiative. In either case, it will not be possible to dedicate all the relevant political forces towards following a joint course before and after the next elections. The resulting uncertainty is bound to shape Portugal's future for several years to come. 